\title{
PEMANFAATAN BIJI ASAM JAWA SEBAGAI KOAGULAN UNTUK MENURUNKAN KADAR BOD DAN TSS LIMBAH CAIR RUMAH MAKAN
}

Ida Lafiyah $^{1)}$ Arifin $^{1)}$ Ulli Kadaria ${ }^{1)}$

${ }^{1)}$ Program Studi Teknik Lingkungan Jurusan Teknik Sipil Fakultas Teknik Universitas Tanjungpura, Pontianak Email : Idalafiyahdisastra@gmail.com

\begin{abstract}
ABSTRAK
Limbah cair yang dihasilkan oleh aktivitas rumah makan mengandung senyawa organik berupa karbohidrat, protein, lemak dan minyak yang apabila masuk ke badan air dapat menyebabkan pencemaran. Pengolahan koagulasi-flokulasi menggunakan koagulan kimia masih menghasilkan endapan mengandung unsure kimia, maka dari itu pemanfaatan koagulan alami seperti biji asam jawa digunakan untuk pengolahan. Penelitian ini bertujuan untuk menentukan efisiensi penggunaan biji asam jawa sebagai koagulan untuk menurunkan kadar BOD dan TSS pada limbah cair rumah makan. Berdasarkan hasil uji pendahuluan, konsentrasi BOD sebesar $2234 \mathrm{mg} / \mathrm{L}$ dan TSS sebesar $1430 \mathrm{mg} / \mathrm{L}$. Nilai tersebut masih berada diatas standar baku mutu berdasarkan Permen LH No 5 Tahun 2014 yaitu konsentrasi BOD sebesar 100 mg/L dan TSS sebesar 100 mg/L. Variabel penelitian yang digunakan adalah pemberian dosis koagulan biji asam jawa dengan variasi dosis $3 \mathrm{gram} / \mathrm{L}, 4 \mathrm{gram} / \mathrm{L}, 5 \mathrm{gram} / \mathrm{L}, 6 \mathrm{gram} / \mathrm{L}$ dan $7 \mathrm{gram} / \mathrm{L}$, dengan kecepatan pengadukan lambat sebesar $100 \mathrm{rpm}$ selama 1 menit dan kecepatan pengadukan lambat sebesar $40 \mathrm{rpm}$ selama 3 menit. Hasil penelitian menunjukkan bahwa terdapat pengaruh antara dosis koagulan dan kecepatan pengadukan terhadap efisiensi penurunan parameter BOD sebesar $90,97 \%$ dari $2.234 \mathrm{mg} / \mathrm{L}$ menjadi 201,8 mg/L dan parameter TSS sebesar $95,18 \%$ dari $1430 \mathrm{mg} / \mathrm{L}$ menjadi $68,88 \mathrm{mg} / \mathrm{L}$. Efektivitas pengolahan belum sesuai yang diharapkan karena hasil yang diperoleh masih melewati baku mutu, untuk penelitian selanjutnya dapat dilakukan penambahan pengolahan lain yang dapat mendukung penurunan pararameter BOD dan TSS agar hasil yang di dapat melewati baku mutu Permen LH No 5 Tahun 2014.
\end{abstract}

Kata kunci : Koagulan, biji asam jawa (Tamarindus indica), koagulasi-flokulasi

\begin{abstract}
Waste water generated from restaurant activities contains organic compounds in the form of carbohydrates, proteins, fats and oils which when entered into water bodies can cause contamination. Coagulation-flocculation processing using chemical coagulant still produces precipitate containing chemical elements, therefore the utilization of natural coagulant such as Tamarind seed is used for treatment process. This study aims to determine the efficiency of the use of Tamarind seeds as a coagulant to reduce levels of BOD and TSS in restaurant waste water. Based on the preliminary test results, the BOD concentration is $2234 \mathrm{mg} / \mathrm{L}$ while TSS concentration is $1430 \mathrm{mg} / \mathrm{L}$. The value are still above the quality standards based on Ministerial Decree of Environment No. 5 Year 2014 in which BOD concentration is $100 \mathrm{mg} / \mathrm{L}$ and TSS concentration is $100 \mathrm{mg} / \mathrm{L}$. The variables used in this research were dosage of coagulant of Tamarind seeds with dosage variation of $3 \mathrm{gram} / \mathrm{L}, 4 \mathrm{gram} / \mathrm{L}, 5 \mathrm{gram} / \mathrm{L}, 6 \mathrm{gram} / \mathrm{L}$ and $7 \mathrm{gram} / \mathrm{L}$, with slow stirring speed of $100 \mathrm{rpm}$ for 1 minute and slow stirring speed of $40 \mathrm{rpm}$ for 3 minutes. The results showed that there was an effect between dosage of coagulant and stirring rate on the $B O D$ removal efficiency by $90.97 \%$ from $2,234 \mathrm{mg} / L$ to $201.8 \mathrm{mg} L$ and TSS by $95.18 \%$ from 1.430 $\mathrm{mg} / \mathrm{L}$ to $68,88 \mathrm{mg} / \mathrm{L}$. The effectiveness of the treatment is not as expected because the results obtained are still above the standard quality in Ministerial Decree of Environment No. 5 Year 2014.
\end{abstract}

Keywords: Coagulant, tamarind seed (Tamarindus indica), coagulation-flocculation. 


\section{Pendahuluan}

Limbah cair adalah air yang mengalami penurunan kualitas, yang merupakan hasil dari berbagai kegiatan manusia sehari-hari. Bertambah dan meningkatnya jumlah penduduk dengan segala kegiatanya, maka jumlah air limbah juga mengalami peningkatan. Salah satu kegiatan manusia sehari-hari yang menghasilkan limbah cair yaitu aktivitas rumah makan, kontaminan utama limbah cair rumah makan berasal dari bahan makanan, proses memasak dan pembersihan peralatan. Metode pengolahan koagulasi-flokulasi yang dikombinasikan dengan sedimentasi merupakan metode yang sudah lama digunakan untuk menurunkan kekeruhan, baik pada limbah cair maupun air baku. Penggunaan koagulan kimia telah banyak digunakan dalam proses pengolahan air seperti Poly Aluminium Chloride (PAC). Keterbatasan penggunaan koagulan kimia ini menghasilkan lumpur/endapan yang masih mempunyai unsur kimia yang dapat membahayakan lingkungan bila dibuang langsung, muncul alternatif penggunaan koagulan biologi yang berasal dari tanaman, salah satunya adalah biji asam jawa (Tamarindus indica L). Penelitian ini bertujuan menentukan efisiensi penggunaan biji asam jawa sebagai koagulan untuk menurunkan BOD dan TSS limbah cair rumah makan.

\section{Metodologi}

\section{a. Waktu dan Tempat Penelitian}

Waktu pelaksanaan penelitian dilakukan selama 3 bulan, penelitian di lakukan di Laboratorium Kualitas Air Teknik Lingkungan Universitas Tanjungpura sebagai tempat pengujian koagulasi-flokulasi, pengambilan sampel limbah cair dilakukan di rumah makan Ayam Dadakan JI. Teuku Umar Pontianak Kota, dan uji BOD dan TSS dilakukan di laboratorium badan penelitian dan pengembangan industry balai riset dan standardisasi industri (Baristand) Pontianak.

\section{b. Alat dan Bahan}

Alat-alat yang digunakan adalah alat floculator digital, gelas beaker, pengaduk, stopwatch, pH meter, ayakan 100 mesh, spatula, gelas ukur, okaos scout pro 2000 gram, kain saring, bak penampung, jeriken, pipa paralon, kran, dan botol air mineral $360 \mathrm{~mL}$ dan $1500 \mathrm{~mL}$. Bahan yang digunakan adalah akuades, biji asam jawa, dan limbah cair rumah makan.

\section{c. Jenis dan Rancangan Penelitian}

Penelitian ini merupakan eksperimental skala laboratorium menggunakan metode deskriptif kuantitatif, penelitian ini merupakan penelitian yang bertujuan menjelaskan fenomena yang ada dengan menggunakan angka-angka untuk menggambarkan karakteristik individu atau kelompok.

\section{- Pengambilan Sampel}

Metode pengambilan sampel menggunakan grab sample, yaitu air limbah yang diambil sesaat pada satu lokasi tertentu.Sampel limbah cair diambil langsung dari rumah makan saat jam makan siang, yaitu antara pukul 12.00 hingga 14.30, waktu ini dipilih karena menghasilkan beban pencemar tertinggi. Sampel yang diukur adalah sampel limbah cair sebelum dan sesudah pengolahan. Sampel limbah cair yang diambil yaitu kurang lebih 20 Liter dan dilakukan pengukuran sampel awal.Sampel di tampung dalam wadah dan dilakukan penyaringan terlebih dahulu dengan menggunakan kain biasa yang mempunyai ukuran pori-pori kecil yang berguna untuk memisahkan limbah cair dan limbah padat, minyak dan lemak yang terkandung di dalam limbah cair rumah makan juga di sisihkan. 


\section{- Preparasi Koagulan Biji Asam Jawa}

Biji asam jawa yang sudah matang berwana kecoklatan dipisahkan dari daging buahnya. Biji yang bersih lalu ditumbuk menjadi serbuk dan kemudian diayak dengan ukuran 100 mesh. Lalu dikeringkan dalam oven dengan suhu $105{ }^{\circ} \mathrm{C}$ selama 30 menit. Serbuk biji asam jawa siap untuk digunakan (Enrico,2008)

\section{- Prosedur Penelitian}

Variasi dosis koagulan serbuk biji asam jawa dilarutkan dalam $500 \mathrm{~mL}$ aquadest untuk selanjutnya digunakan sebagai koagulan.Variasi dosis koagulan yang digunakan : 3 gram; 4 gram; 5 gram; 6 gram; dan 7 gram dilakukan untuk mengetahui pengaruh dosis koagulan biji asam jawa yang efisien. Beaker diisi dengan sampel limbah cair rumah makan sebesar $500 \mathrm{~mL}$. Kemudian koagulan ditambahkan ke dalam beaker sebanyak 50 $\mathrm{mL}$. Sampel dilakukan pengadukan, kecepatan pengadukan yaitu koagulasi sebesar 100 rpm selama 1 menit dan flokulasi sebesar $40 \mathrm{rpm}$ selama 3 menit, selanjutnya diendapkan selama 60 menit kemudian konsentrasi BOD dan TSS dianalisis.

\section{- Kerangka Penelitian}

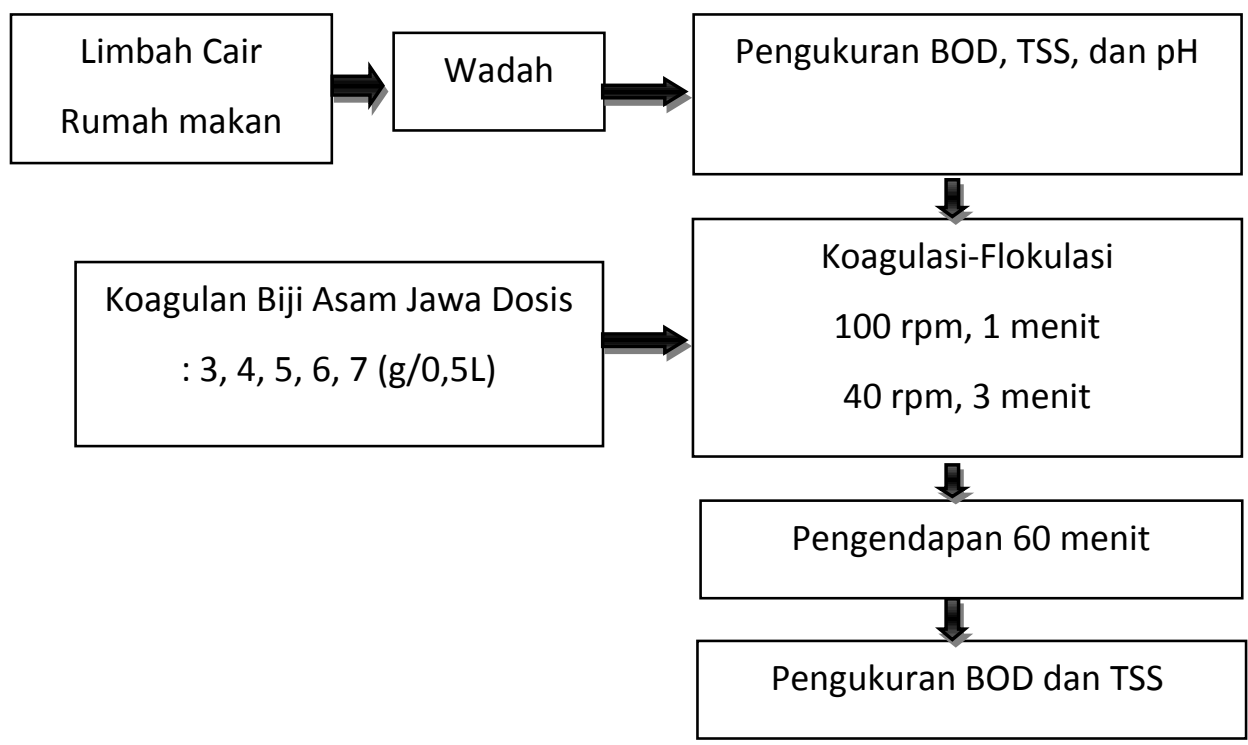

Gambar 1. Bagan Alir Penelitian

\section{- $\quad$ Analisis Data}

Analisa yang dilakukan pada penelitian ini analisa efisiensi koagulan yang dilihat dari nilai penurunan nilai BOD dan TSS. Penurunan tersebut dihitung dengan membandingkan nilai pada influen dan efluen yang akan dinyatakan dalam persen (\%). Perhitungan efisiensi (Metcalf dan Eddy, 1991):

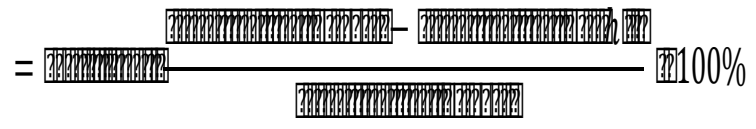

Hasil penelitian ini juga dianalisis menggunakan uji statistik dengan menggunakan aplikasi minitab, uji satistik ini bertujuan untuk mengetahui korelasi antara dua variabel yaitu koagulan biji asam jawa dengan penurunan parameter dan diketahui persamaan regresi liniernya. 


\section{Hasil dan Pembahasan}

\section{a. Karakteristik Limbah Cair Rumah Makan}

Limbah cair rumah makan yang dianalisis merupakan limbah cair yang berasal dari aktivitas pencucian bahan makanan dan cuci piring. Karakteristik limbah cair rumah makan yang melebihi baku mutu diakibatkan oleh kandungan bahan-bahan organik, senyawa organik yang terkandung dalam limbah cair rumah makan berupa karbohidrat, protein, minyak dan lemak. Hasil uji akan dibandingkan dengan baku mutu limbah cair bagi kegiatan domestik rumah makan menurut Peraturan Menteri Lingkungan Hidup No 5 Tahun 2014. Karakteristik awal limbah cair rumah makan diketahui dengan mengukur parameter limbah tersebut, secara fisik karakteristik limbah cair rumah makan berwarna kuning dan keruh serta memiliki bau.Karakteristik limbah cair yang dianalisis pada uji pendahuluan yaitu BOD dan TSS. Hasil analisis karakteristik air limbah cair rumah makan dapat dilihat pada berikut ini :

Tabel 1. Karakteristik Limbah Rumah Makan

\begin{tabular}{cccccc}
\hline No & Parameter & Metode / Alat & Satuan & $\begin{array}{c}\text { Hasil } \\
\text { Analisis }\end{array}$ & $\begin{array}{c}\text { Standar Baku Mutu } \\
\text { (PERMEN LH No 5 } \\
\text { Tahun 2014) }\end{array}$ \\
\hline 1 & BOD & IK 5.4.2.11.02 & $\mathrm{mg} / \mathrm{L}$ & 2234 & 100 \\
2 & TSS & SNI 06-6989.3- & $\mathrm{mg} / \mathrm{L}$ & 1430 & 100 \\
3 & $\mathrm{pH}$ & $\begin{array}{c}2004 \\
\mathrm{pH} \text { Meter }\end{array}$ & & 6.1 & $6-9$ \\
\hline
\end{tabular}

Sumber : Analisis Hasil (2017)

Table diatas menunjukkan bahwa konsentrasi parameter BOD dan TSS limbah cair rumah makan yang dianalisa telah melewati baku mutu yaitu nilai BOD sebesar $2234 \mathrm{mg} / \mathrm{L}$ dan TSS sebesar $1430 \mathrm{mg} / \mathrm{L}$, sedangkan nilai $\mathrm{pH}$ berada pada kondisi normal atau sesuai baku mutu yaitu 6,1. Menurut Permen LH no 5 tahun 2014 standar baku mutu limbah cair rumah makan yang di izinkan dibuang ke badan perairan untuk konsentrasi BOD yaitu sebesar $100 \mathrm{mg} / \mathrm{L}$ dan TSS sebesar $100 \mathrm{mg} / \mathrm{L}$ sehingga limbah cair rumah makan tersebut masih belum layak dibuang ke badan perairan, oleh sebab itu konsentrasi parameter BOD dan TSS dilakukan pengolahan untuk mengurangi pencemaran.

\section{b. PreparasiKoagulan Biji Asam Jawa (Tamarindusindica)}

Pemilihan biji asam jawa yang baik untuk dijadikan koagulan sebaiknya biji asam jawa yang matang di pohon yang berwarna kecoklatan. Asam jawa yang masih utuh dipisah antara cangkang, isi dan bijinya. Biji asam jawa yang sudah terpisah dicuci dan dijemur agar mempermudah dalam penumbukan, kemudian setelah kering ditimbang yang selanjutnya ditumbuk dan di ayak dengan ayakan ukuran 100 mesh. Ukuran 100 mesh sendiri didapat setelah melihat beberapa penelitian terdahulu dengan menggunakan koagulan biji asam jawa, setelah dilakukan perbandingan antara beberapa ukuran koagulan didapat ukuran 100 mesh lebih efektif dalam proses koagulasi/flokulasi. Penelitian sebelumnya yang dilakukan Annas dkk (2011) dengan menggunakan uji data statistik menunjukkan adanya pengaruh dua variabel terhadap penurunan parameter yaitu dosis dan ukuran partikel koagulan biji asam jawa. Variasi yang digunakan dalam penelitian tersebut yaitu partikel koagulan dengan ukuran 52 mesh, 100 mesh, 170 mesh, dan 250 mesh, dari empat variasi partikel tersebut partikel dengan ukuran 100 mes lebih baik penurunannya di setiap parameter dibanding ukuran partikel koagulan lain. Biji yang sudah diayak kemudian di oven dengan suhu $105^{\circ} \mathrm{C}$, 
pengovenan koagulan dilakukan dengan tujuan untuk menghilangkan kadar airnya yang dimana air akan menguap pada suhu diatas $100^{\circ} \mathrm{C}$. Pengovenan koagulan selama 30 menit dilakukan karena selama dalam waktu tersebut suhu berada pada keadaan konstan dan proses penguapan terjadi sehingga koagulan yang dihasilkan kandungan airnya sudah menguap dan koagulan dalam keadaan kering.

\section{c. Penurunan Konsentrasi BOD pada Limbah Cair Rumah Makan}

Penurunan parameter BOD pada limbah cair rumah makan menggunakan variasi dosis koagulan biji asam jawa dapat dilihat pada tabel berikut ini :

Tabel 1. Hasil Analisis Penurunan Parameter BOD

\begin{tabular}{|c|c|c|c|c|c|c|c|c|c|}
\hline \multirow[t]{2}{*}{ No } & \multirow{2}{*}{$\begin{array}{c}\text { Variasi } \\
\text { Koagulan } \\
\text { (Gram) }\end{array}$} & \multirow{2}{*}{$\begin{array}{c}\text { Konsentrasi } \\
\text { BOD Awal } \\
\text { (mg/L) }\end{array}$} & \multicolumn{5}{|c|}{$\begin{array}{l}\text { Konsentrasi Akhir (mg/L) } \\
\text { Pengulangan ke- }\end{array}$} & \multirow{2}{*}{$\begin{array}{l}\text { Rata- } \\
\text { rata } \\
\text { (mg/L) }\end{array}$} & \multirow{2}{*}{$\begin{array}{c}\text { Efesiensi } \\
\text { Penurunan } \\
\text { (\%) }\end{array}$} \\
\hline & & & I & II & III & IV & V & & \\
\hline 1 & 3 & & 222 & 220 & 237 & 241 & 252 & 234,4 & 89,51 \\
\hline 2 & 4 & & 221 & 188 & 172 & 211 & 217 & 201,8 & 90,97 \\
\hline 3 & 5 & 2234 & 215 & 246 & 219 & 227 & 238 & 229 & 89,75 \\
\hline 4 & 6 & & 251 & 213 & 272 & 243 & 256 & 247 & 88,94 \\
\hline 5 & 7 & & 247 & 242 & 255 & 281 & 266 & 258,2 & 88,44 \\
\hline
\end{tabular}

Sumber : Hasil Analisis 2017

Tabel diatas menunjukkan penurunan konsentrasi parameter BOD menggunakan koagulan biji asam jawa mengalami penurunan dari sampel awal limbah. Variasi dosis dilakukan pengulangan sebesar lima kali, dari lima kali pengulangan tersebut didapatkan nilai rata-rata, setiap variasi dosis yang menunjukan perbandingan dosis optimum penurunan parameter BOD pada limbah cair rumah makan. Nilai efisiensi penurunan didapat setelah nilai rata-rata diketahui dan ditunjukan dengan presentasi nilai tersebut, kemudian pada efisiensi dari lima variasi dosis dibandingkan dan dilihat nilai mana yang paling efisien. Nilai efisiensi penurunan parameter BOD dari lima variasi dosis tersebut yaitu 3 gram sebesar 89,51\%, 4 gram sebesar 90,97\%, 5 gram sebesar 89,75\%, 6 gram sebesar $88,94 \%$ dan 7 gram sebesar $88,44 \%$. Semua nilai didapat kemudian dapat diketahui nilai efisiensi mana yang paling optimum penurunannya, dan dari hasil tersebut penurunan konsentrasi BOD yang paling besar didapat pada variasi dosis koagulan 4 gram yaitu sebesar $90,97 \%$. Efisiensi penurunan dapat dilihat pada gambar berikut :

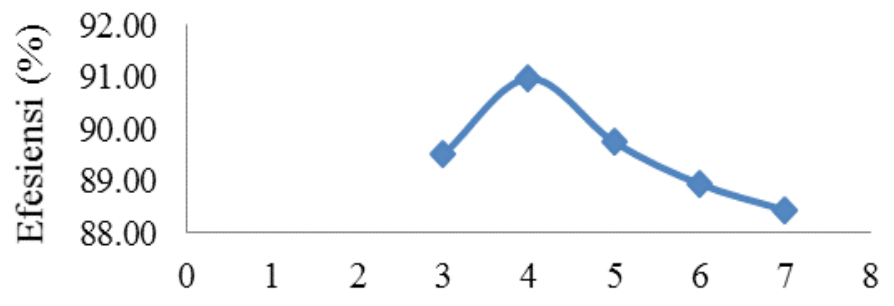

Variasi Dosis Koagulan $(\mathrm{mg} / 0,5 \mathrm{~L})$

Gambar 1. Grafik Hubungan Dosis Biji Asam Jawa Terhadap Efisiensi Penurunan Parameter BOD 
Gambar tersebutmenunjukkan fluktuasi grafik dimana dari dosis koagulan 3 gram ke dosis koagulan 4 gram terjadi kenaikan dan dari 4 gram terhadap 5 gram, 6 gram dan 7 gram terjadi penurunan kembali. Penurunan parameter BOD dapat terjadi karena partikel yang sangat halus dan koloid bersifat stabil dalam air dan di non-stabilkan muatan permukaannya dengan zat koagulan sehingga terjadi gaya tarik menarik membentuk flok pada proses koagulasi-flokulasi. Partikel tersuspensi yang telah membentuk flok yang berasal dari proses koagulasi dapat dipisahkan dari limbah cair rumah makan melalui proses sedimentasi atau pengendapan.

fluktuasi yang terjadi pada grafik menunjukkan bahwa semakin besar gram koagulan atau semakin banyak koagulan biji asam jawa yang ditambahkan kedalam limbah cair rumah makan tidak menjamin semakin besar juga penurunan karakteristik parameter BOD pada limbah tersebut. Diperjelas pada penelitian sebelumnya mengenai biji asam jawa sebagai koagulan dalam limbah cair industri tahu yang dilakukan oleh Annas dkk (2011) dengan variasi dosis yang sama juga menunjukan fluktuasi pada grafikyang turun-naik, dari variasi dosis 5 gram/L, 10 gram/L, 20 gram/L, 30 gram/L, 40 gram/L dan 50 gram/L dosis penurunan yang optimum terdapat pada variasi dosis 10 gram/L dengan presentasi penurunan sebesar 91,50\% untuk TSS dan 80,54\% untuk BOD. Faktor lain yang dapat mempengaruhi terjadinya fluktuasi tersebut diantaranya adalah $\mathrm{pH}$ air, dimana $\mathrm{pH}$ air berperan dalam membantu terjadinya proses koagulasi-flokulasi untuk menghasilkan hasil yang baik. Nilai pH limbah cair rumah makan sebesar 6,1 dan pada keadaan tersebut $\mathrm{pH}$ berada pada keadaan normal atau masih berada pada baku mutu, dikombinasikan dengan nilai $\mathrm{pH}$ koagulan maka didapat hasil dari koagulasiflokulasi tersebut. Hasil koagulasi-flokulasi setiap variasi dosis tidak sama, hal tersebut disebabkan karena nilai pH koagulan setiap variasi juga berbeda-beda, dapat dilihat pada tabel berikut ini :

Tabel 3.Nilai pH Dosis Koagulan Biji Asam Jawa Setiap Variasi

\begin{tabular}{ccc}
\hline No & Variasi dosis & $\mathrm{pH}$ \\
\hline 1 & 3 gram & 5,2 \\
2 & 4 gram & 4,1 \\
3 & 5 gram & 3,4 \\
4 & 6 gram & 2,8 \\
5 & 7 gram & 2,2 \\
\hline
\end{tabular}

Sumber : Hasil Analisis 2017

Tabel diatas menunjukkan bahwa semakin banyak koagulan yang dilarutkan maka semakin asam nilai $\mathrm{pH}$ yang dihasilkan, dimana diperkirakan telah terjadi denaturasi protein akibat keasaman $\mathrm{pH}$ terlalu ekstrim yang menyebabkan efisiensi penurunan konsentrasi BOD kembali menurun. Diperjelas oleh penelitian terdahulu yang dilakukan Enrico tahun 2008 mengenai pemanfaatan biji asam jawa (Tamarindus indica) sebagai koagulan alternatif dalam proses penjernihan limbah cair industri tahu menunjukkan bahwa koagulan biji asam jawa bekerja efektif pada $\mathrm{pH} 4$ disebabkan karena kandungan asam tertarat yang terdapat dalam bijinya sehingga ion $\mathrm{H}^{+}$pada asam tertarat tersebut berikatan dengan ion negatif pada partikel koloid limbah cair membentuk suatu lapisan yang lama-lama akan semakin besar yang disebut flok.

Dalam ekstrak biji asam jawa terkandung ion-ion logam seperti $\mathrm{Ca}^{2+}, \mathrm{Mg}^{2+}$ dan $\mathrm{Fe}^{3+}$ dimana berdasarkan deret kereaktifan unsur ion $\mathrm{Ca}^{2+}$ lebih reaktif dibandingkan ion $\mathrm{Mg}^{2+}$ dan $\mathrm{Fe}^{3+}$. Bahan organik yang terkandung dalam limbah cair rumah makan memiliki muatan negatif sehingga dapat berikatan dengan ion-ion positif yang terkandung dalam koagulan biji asam jawa. Ikatan-ikatan tersebut membentuk flok-flok yang lebih besar 
setelah mengalami proses pengadukan lambat dimana partikel saling bertubrukan dan tetap bersatu untuk kemudian mengendap sebagai endapan. Biji asam jawa yang berfungsi sebagai koagulan dalam proses koagulasi-flokulasi dapat menurunkan konsentrasi parameter BOD pada limbah cair rumah makan karena terdapat kandungan tanin. Tanin adalah senyawa phenolic yang larut dalam air, dengan berat molekul antara 500-3000 dapat mengendapkan protein dari larutan. Menurut Gery dan Atiek (2013) dalam $500 \mathrm{mg}$ ekstra biji asam jawa, terdapat $0,6 \mathrm{mg}$ ion $\mathrm{Ca}^{2+}, 0,9 \mathrm{mg} \mathrm{Mg}^{2+}$, dan $0,4 \mathrm{mg}$ ion $\mathrm{Fe}^{2+}$, berikut reaksi yang terjadi antara $\mathrm{Ca}^{2+}, \mathrm{OH}^{-}$dan senyawa limbah cair rumah makan :

Air limbah $+\mathrm{Ca}^{2+}+\mathrm{H}_{2} \mathrm{O} \rightarrow \mathrm{Ca}(\mathrm{OH})_{2} \downarrow \mathrm{H}^{+}$

Air limbah $+\mathrm{Fe}^{3+}+\mathrm{H}_{2} \mathrm{O} \rightarrow \mathrm{Fe}(\mathrm{OH})_{3} \downarrow \mathrm{H}^{+}$

\section{d. Penurunan Parameter TSS pada Limbah Cair Rumah Makan}

Tabel 4. Hasil Analisis Penurunan Konsentrasi TSS

\begin{tabular}{cccccccccc}
\hline No & $\begin{array}{c}\text { Variasi } \\
\text { Koagulan } \\
\text { (Gram) }\end{array}$ & $\begin{array}{c}\text { Konsentrasi } \\
\text { TSS Awal } \\
\text { (mg/L) }\end{array}$ & \multicolumn{6}{c}{$\begin{array}{c}\text { Konsentrasi Akhir (mg/L) } \\
\text { Pengulangan ke- }\end{array}$} & \multicolumn{2}{c}{$\begin{array}{c}\text { Rata-rata } \\
\text { (mg/L) }\end{array}$} & $\begin{array}{c}\text { Efesiensi } \\
\text { Penurunan (\%) }\end{array}$ \\
\cline { 5 - 8 } & 3 & & 127 & 117 & 124 & 108 & 132 & 121,6 & 91,50 \\
2 & 4 & & 86,4 & 66 & 53 & 63 & 76 & 68,88 & 95,18 \\
3 & 5 & 1430 & 78 & 47 & 88 & 89 & 67 & 73,8 & 94,84 \\
4 & 6 & & 105 & 72 & 109 & 102 & 104 & $9, .4$ & 93,12 \\
5 & 7 & & 134 & 105 & 107 & 118 & 134 & 119,6 & 91,64 \\
\hline
\end{tabular}

Sumber : Hasil Analisis 2017

Tabel diatas merupakan hasil pengujian limbah cair rumah makan dengan konsentrasi penurunan yaitu parameter TSS. Data yang diperoleh untuk parameter TSS tidak beda dengan data penurunan parameter BOD dan proses pengolahan yang sama yaitu koagulasi-flokulasi, variasi gram sama yaitu lima variasi dan dilakukan pengulangan sebesar lima kali untuk setiap variasi. Setelah dilakukan lima kali pengulangan kemudian di dapat nilai rata-rata setiap variasi, yang selanjutnya menghasilkan nilai efisiensi dari setiap variasi. Setelah didapat lima nilai efisiensi dari setiap variasi dosis, dilihat variasi mana yang lebih besar penurunannya. Sama dengan parameter BOD, pada penurunan parameter TSS dengan menggunakan dosis biji asam jawa sebagai koagulan didapat penurunan yang paling efisien sebesar $95,18 \%$ pada variasi dosis 4 gram. Efisiensi penurunan dapat dilihat pada gambar berikut :

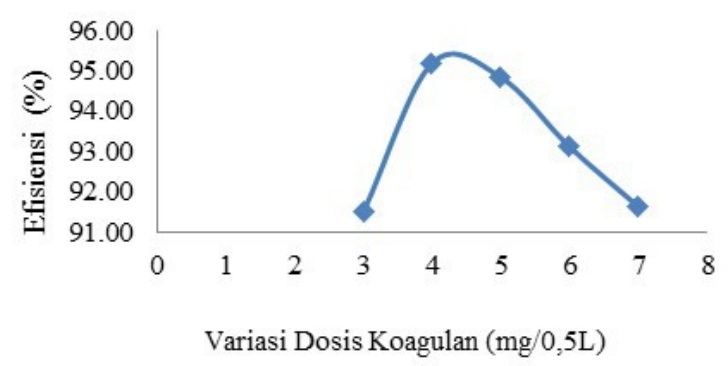

Gambar 2. Grafik Hubungan Dosis Koagulan Biji Asam Jawa Terhadap Efisiensi Penurunan Parameter TSS 
Gambar diatas menunjukan fluktuasi juga terjadi pada parameter TSS. Hal tersebut menunjukan adanya keterkaitan antara parameter BOD dan parameter TSS, dimana kandungan koagulan biji asam jawa yang dapat menurunkan parameter BOD berpengaruh juga terhadap penurunan parameter TSS. Dijelaskan oleh penelitian yang dilakukan Nurika dkk,(2007) menyatakan bahwa penurunan parameter BOD disebabkan karena koagulan biji asam jawa mampu mengikat bahan-bahan organik limbah cair rumah yang komponen besarnya berupa protein ( $\mathrm{N}$-total) menjadi cepat mengendap dan mengumpul, hal tersebut berpengaruh terhadap penurunan karakteristik parameter TSS. Bahan organik yang terkandung dalam air limbah memiliki muatan negatif sehingga dapat berikatan dengan ion-ion positif yang terkandung dalam koagulan. Ikatan-ikatan tersebut membentuk flok-flok yang lebih besar setelah mengalami proses pengadukan lambat dimana partikel saling bertubrukan dan tetap bersatu untuk kemudian mengendap sebagai endapan.

Faktor lain yang mendukung terjadinya penurunan parameter TSS pada limbah cair rumah makan yaitu waktu penjernihan. Waktu pengendapan dapat berpengaruh terhadap penurunan parameter TSS limbah cair rumah makan, karena semakin lama waktu pengendapan maka semakin banyak endapan yang terjadi atau semakin lama waktu yang digunakan maka menghasilkan penyisihan yang lebih besar lagi. Penelitian yang dilakukan menggunakan waktu 60 menit, karena dalam waktu selama itu diperkirakan penyisihan terjadi dan banyaknya endapan yang dihasilkan mempengaruhi penurunan parameter TSS yang terjadi cukup besar juga.

\section{Analisis Korelasi dan Regresi}

Penelitian pemanfaatan biji asam jawa sebagai koagulan pengolah limbah cair rumah makan ini menggunakan garis regresi dan korelasi untuk menganalisisnya dengan menggunakan aplikasi minitab, berikut merupakan hasil analisisnya :

\section{a. Korelasi dosis koagulan terhadap parameter BOD}

Setelah data di plot kedalam aplikasi minitab, didapat hasil korelasi pearson dosis koagulan terhadap parameter BOD $(\mathrm{mg} / \mathrm{L})=0,466$ sedangkan nilai P-value $=0.019$. Hasil tersebut menunjukkan nilai $r=0,466$ (mendekati -1 ) dan $P=0,01(<0,05)$, jadi hasil penelitin ini menyatakan bahwa adanya hubungan korelasi antara dua variabel. Nilai $r$ yang berada diantara -1 dan +1 menunjukkan bahwa terjadi kecenderungan hasil variabel lain yang mengikutinya terjadi penurunan yang tidak konstan atau adanya fluktuasi pada grafik.

\section{b. Korelasi dosis koagulan terhadap parameter TSS}

Korelasi pearson dosis koagulan terhadap parameter TSS $(\mathrm{mg} / \mathrm{L})=0,142$ sedangkan nilai $P$-value $=0,498$. Hasil tersebut menunjukkan nilai $r$ yang mendekati -1 dan $\mathrm{P}>0,05$ dapat disimpulkan bahwa tidak ada korelasi antara dua variabel tersebut dan kecenderungan hasil variabel lain yang semakin menurun. Hasil yang demikian dapat diakibatkan adanya faktor lain yang berpengaruh besar terhadap proses pengolahan seperti proses pengendapan.Data diatas menunjukkan hasil korelasi dosis koagulan terhadap parameter BOD memiliki hubungan korelasi, sedangkan untuk parameter TSS menunjukkan nilai yang menandakan tidak adanya hubungan korelasi. Hasil tersebut menyatakan bahwa hanya korelasi dosis koagulan terhadap parameter BOD saja yang dapat diteruskan ke persmaan regresi linier. Berikut merupakan persamaan regresi linier dosis koagulan terhadap parameter BOD : 


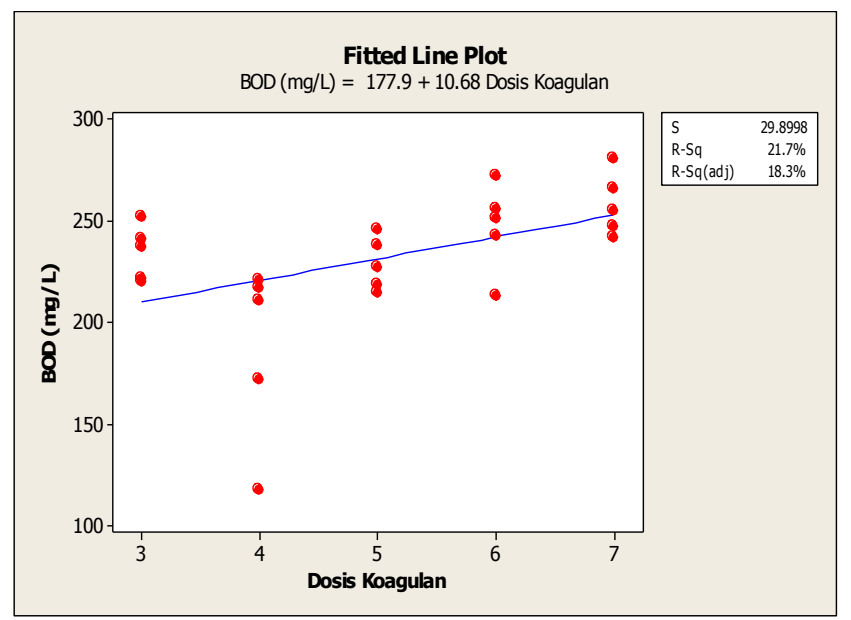

Gambar 4. Grafik Variasi Dosis Koagulan Terhadap Penurunan Parameter BOD (mg/L)

Hasil output dari uji regresi ini didapat dari persamaan regesi diantaranya adalah nilai determinan atau R-Squared. Determinan adalah kebertepatan titik yang diamati dengan garis model, dalam penelitian ini nilai determinan $21,7 \%$ menunjukkan bahwa antara variable dosis koagulan $(\mathrm{X})$ terhadap parameter BOD $(\mathrm{Y})$ hanya dapat diterangkan secara linier sebesar $21,7 \%$. Hasil tersebut menunjukkan adanya hubungan antara variable dosis koagulan terhadap parameter BOD, tetapi penggambaran oleh persamaan regresi tidak begitu besar karena titik yang berada pada garis regresi hanya sebesar $21,7 \%$ saja.

\section{Kesimpulan dan Saran}

\section{a. Kesimpulan}

Kesimpulan yang dapat diambil dari penelitian ini yaitu koagulan biji asam jawa mampu menurunkan parameter BOD dan TSS limbah cair rumah makan dengan dosis optimum sebesar 4 gram, dengan presentasi efisiensi penurunan parameter BOD yaitu sebesar $90,97 \%$ dari $2234 \mathrm{mg} / \mathrm{L}$ menjadi 201,8 mg/L dan parameter TSS sebesar 95,18\% dari $1430 \mathrm{mg} / \mathrm{L}$ menjadi $68,88 \mathrm{mg} / \mathrm{L}$.

\section{b. Saran}

Dari hasil analisa dan pembahasan pada penelitian ini, disarankan beberapa perbaikan sebagai berikut:

1. Penelitian selanjutnya dapat ditambahkan parameter fosfat hasil dari pencucian alat makan dan masak dengan menggunakan koagulan biji asam jawa.

2. Penelitian selanjutnya sebaiknya dilakukan variasi kecepatan pengadukan dan waktu pengendapan yang lebih lama agar didapat hasil yang lebih akurat.

3. Penelitian selanjutnya dapat dilakukan pengaturan $\mathrm{pH}$ kogulan agar grafik penurunannya konstan.

4. Penelitian selanjutnya dapat dilakukan penambahan pengolahan lain yang dapat mendukung penurunan pararameter BOD dan TSS agar hasil yang di dapat melewati baku mutu. 


\section{Ucapan Terimakasih}

Dengan selesainya penelitian ini saya mengucapkan terimakasih yang sebesarbesarnya kepada Allah SubhanallahuWaTa'ala, kedua orang tua saya beserta keluarga, kepada dosen pembimbing yang bersedi membimbing yaitu Bapak Dr. Arifin, S.T., M. Eng,Sc. dan Ibu UlliKadaria, S.T., M.T., kepada dosen penguji saya yang juga bersedia membimbing saya yaitu Ibu YulisaFitrianingsih, S.T., M.T. dan Ibu HerdaDesmaiani, S.Si., M.Sc., serta teman-teman Teknik Lingkungan 2012 dan semua orang yang telah berperan dalam membantu penelitian yang tidak dapat disebut satu-persatu. Harapan saya penelitian ini dapat bermanfaat bagi semua dan dapat dipergunakan sebagaimana mestinya.

\section{Daftar Pustaka}

Enrico,B.2008. Pemanfaatan Biji asam jawa (Tamarindus indica) Sebagai Koagulan Alternatif Dalam Proses Penjernihan Limbah Cair Industri Tahu. Tesis. Lampung:Program Studi Teknik Kimia Universitas Sumatra Utara

Metcafl dan Eddy. 1991. Wastewater Engineering Treatment, Disposal, Reuse. New Delhi. McGraw. Hillbook Company

Peraturan Menteri Lingkungan Hidup Republik Indonesia Nomor 5 Tahun 2014 Tentang Baku Mutu Pencemaran Air Limbah 